\title{
Pengembangan Modul Pencemaran Lingkungan Berbasis Problem Posing Disertai Spider Concept Map untuk Memberdayakan Keterampilan Proses Sains dan Kemampuan Menganalisis Siswa SMAN 1 Sumberlawang
}

\author{
The Module Development of Environmental Pollution based on Problem \\ Posing with Spider Concept Map to Empower Student's Science Process Skills \\ and Student's Analyze Abilities of Sumberlawang 1 Senior High School
}

\author{
WAHYONO, SUCIATI, SUTARNO \\ SD Aisyah Gemolong Sragen \\ Program Studi Pendidikan Biologi FKIP Universitas Sebelas Maret \\ Jurusan Biologi FMIPA Universitas Sebelas Maret \\ Jl. Ir. Sutami No. 36A Kentingan Surakarta \\ *email:1pdi_ic@yahoo.com
}

Manuscript received: 16 Mei 2013 Revision accepted: 19 Juli 2014

\begin{abstract}
The research and the development of the modules aims to know: 1) The characteristic of environmental pollution module based on problem posing with spider concept map; 2) The procedure of developing environmental pollution module based on problem posing with spider concept map; 3) The feasibility of environmental pollution module based on problem posing with spider concept map to empower students' science process skills and students' analyze abilities; and 4) Effectiveness of environmental pollution module based on problem posing with spider concept map to to empower students' science process skills and students' analyze abilities. The method used in the research is Research and Development (R\&D) modification of Borg \& Gall (Tim Puslitjaknov, 2008: 10-11). The subject used in preliminary field test consisting of 10 students', the main field subject consisting of 10 students' and opeational field subject consisting of 32 students' SMAN 1 Sumberlawang. The instruments used in the research, mainly: questionaire, observation, interview and test. The operational field was conducted using one group pretest-postest design. Students' science process skills and students' analyze abilities were tested by paired sample t-test and counted by normalized gain score. The results of the research can be concluded that: 1) The characteristic of vironmental pollution module based on problem posing with spider concept map, mainly: aspect of students' science process skills and students' analyze abilities, science literate abilities (be able to understand, read, write and think in terms of science); 2) The development of environmental pollution module based on problem posing with spider concept map used modification Borg \& Gall, mainly: preliminary research, planning, developing the initial products, preliminary field test, major product revision, main field test, the operational product revision, operational field, revision of the final product, the dissemination and the implementation of the product; 3) The feasibility of environmental pollution module based on problem posing with spider concept map average obtained is 3,51 that's "very good" categories; and 4) The environmental pollution module based on problem posing with spider concept map is effective to empowering students' science process skills with 0,60 N-gain score that's "middle" categories and empowering students' analyze abilities with 0,57 N-gain score that's "middle" categories.
\end{abstract}

Keywords: environmental pollution, problem posing, spider concept map, students' science process skills and students' analyze abilities

\section{LATAR BELAKANG}

Pendidikan merupakan salah satu upaya untuk mengembangkan dan meningkatkan sumber daya manusia yang berkualitas. Menurut Putranto (2010), salah satu upaya yang dapat dilakukan untuk meningkatkan sumber daya manusia adalah meningkatkan kualitas pendidikan yang berfokus pada pengembangan kemampuan berfikir siswa dalam menyongsong abad 21. Pendidikan yang sesuai dengan perkembangan abad 21 lebih mengandalkan pada pengembangan keterampilan yang meliputi, keterampilan berpikir, keterampilan memecahkan masalah dan keterampilan berkomunikasi yang men-dukung optimalisasi pada proses pencapaian pendidikan.

Pendidikan sains diharapkan dapat menjawab tantangan perkemba-ngan abad 21 karena memiliki karakteristik pembelajaran yang mengacu pada hakikat sains. hakikat pembelajaan biologi sebagai salah satu dari ilmu sains meliputi: proses, produk, sikap dan teknologi (Carin \& Evans dalam Suciati, 2011). Hakikat sains sebagai proses keterampilan dalam pembelajaran diarahkan pada pembentukan keterampilan proses sains yang merupakan kete-rampilan kinerja siswa dalam mengamati, mengumpulkan data, mengolah data, menginterpretasikan data, menyimpulkan dan mengkomunikasikan. Sains 
sebagai produk, berarti dalam Biologi terdapat produk yang berupa konsep, dalil, hukum, teori, dan prinsip yang sudah diterima kebenaranya (Carin \& Evans dalam Suciati, 2011). Sains sebagai sikap berarti dalam Biologi terkandung pengembangan sikap ilmiah diantaranya: terbuka, obyektif, berorientasi pada kenyataan, bertanggungjawab dan beker-ja sama. Adapun, sains sebagai teknologi berarti biologi berkaitan erat dan digunakan dalam kehidupan sehari-hari untuk memecahkan berbagai permasa-lahan yang muncul.

Karakteristik pendidikan sains tersebut diharapkan dapat mendorong siswa untuk membangun pengetahuannya sendiri untuk memecahkan permasalahan dalam kehidupan sehari-hari yang me- nuntut berpikir kritis terutama ke-mampuan menganalisis. Kemampuan menganalisis adalah untuk merinci atau menguraikan suatu masalah (soal) menjadi bagian-bagian yang lebih kecil (komponen) serta mampu untuk memahami hubungan diantara bagian-bagian tersebut (Suherman dan Sukjaya, 1990: 49). Pendidikan sains yang diharapkan dapat melatih siswa untuk menjawab tantangan permasalahan abad 21 perlu dibekali dengan keterampilan proses sains dan kemampuan berpikir kritis terutama kemampuan menganalisis.

Pada kenyataannya, kemampuan siswa dibidang sains masih kurang. Berdasarkan data PISA sejak tahun $2000-$ 2009 menunjukkan bahwa kemampuan literasi sains siswa indonesia rendah. Literasi sains berkaitan dengan keterampilan proses sains, karena dalam literasi sains terdapat aktifitas mengidentifikasi, menyimpulkan dan mengkomunikasikan (Toharudin, et al., 2011). Tahun 2000 siswa Indonesia berada pada peringkat ke-38 dari 41 negara peserta, tahun 2003 pada peringkat ke-38 dari 40 negara peserta, tahun 2006 peringkat ke-50 dari 57 negara peserta dan tahun 2009 peringkat ke-60 dari 65 negara peserta (Balitbang Kemendikbud, 2014). Sedangkan Berdasarkan data PISA (2013), menunjukkan bahwa siswa Indonesia berada pada peringkat ke-64 dari 65 negara peserta.

Hasil observasi di SMAN 1 Sumberlawang menunjukkan bahwa siswa kesulitan dalam bepikir analisis. Hal tersebut ditunjukkan dengan rendahnya hasil belajar siswa terutama ketika dituntut menyelesaikan soalsoal yang membutuhkan analisis yang meliputi kemampuan menguji ide, mengenali argumen dan mengenali alasan dan pernyataan (Facione, 2001). Hasil analisis menunjukkan bahwa siswa mengalami kesulitan dalam menguji ide sebesar $(53,12 \%)$, kemampuan mengenali argumen $(62,50 \%)$ dan kemampuan mengenali alasan dan pernyataan $(68,75 \%)$.

Salah satu masalah yang dihadapi dunia pendidikan adalah lemahnya proses pembelajaran (Adi, 2009). Hasil studi pustaka di SMAN 1 Sumberlawang melalui Standar Nasional Pendidikan, menunjukkan bahwa standar proses memiliki capaian terendah yaitu sebesar $86,67 \%$ (Kemendikbud, 2013). Rendahnya standar proses dipengaruhi oleh kurang optimalnya proses pembelajaran Kurang optimalnya proses pembelajaran juga berdampak pada rendahnya keterampilan proses sains siswa. Hal ini ditunjukkan lemahnya kemampuan siswa dalam: merumuskan masalah $(56,25 \%)$, membuat hipotesis $(62,50 \%)$ dan mengkomunikasikan hasil percobaan $(68,75 \%)$.

Ditinjau dari aspek bahan ajar, pembelajaran kurang didukung oleh bahan ajar yang memadai. Hasil analisis profil buku ajar di SMAN 1 Sumberlawang berupa buku paket yang umumnya ada di pasaran. Buku ajar tersebut memiliki cakupan materi yang sangat luas, kegiatan praktikum siswa kurang melibatkan keterampilan proses sains karena sudah ditentukan alat, bahan dan cara kerja.

Materi Pencemaran Lingkungan merupakan salah satu materi yang masuk dalam kisi-kisi ujian nasional. Berdasarkan analisis kesulitan belajar siswa menunjukkan bahwa hasil UN pada materi Pencemaran Lingkungan di SMAN 1 Sumberlawang rata-rata ketuntasan rendah, yaitu sebesar 62,50\% (Balitbang, 2013). Sementara materi Pencemaran Lingkungan merupakan materi yang berhubungan dengan permasalahan kehidupan sehari-hari siswa, sehingga penting bagi siswa untuk dipelajari.

Adanya kesenjangan tersebut perlu adanya solusi yaitu berupa modul Pencemaran Lingkungan yang diharapkan mampu memberdayakan kemampuan siswa dalam hal menguasai produk sains, seperti konsep-konsep, menggunakan metode ilmiah untuk memecahkan masalah, memiliki nilai yang berkaitan dengan masalah sikap setelah terbiasa mempelajari dan menguasai produk dan proses sains.

Problem posing adalah model pembelajaran yang dapat melatih siswa memecahkan masalah yang dapat mendorong siswa dalam mempelajari materi secara lebih terorganisir dan terkoordinir serta mengarahkan siswa lebih aktif mencari sumberbelajar dari berbagai literatur guna membantu pada saat memecahkan masalah hingga mencari solusi dari suatu permasalahan melalui langkahlangkah pembelajaran untuk mengkonstruksi pengetahuannya sendiri. Sintaks dalam problem posing diharapkanmemfasilitasi siswa dalam rangka membangun pengetahuannya, meliputi: mengidentifikasi masalah, menampilkan masalah, membahas alternatif pemecahan masalah, mendiskusikan masalah, menerapkan konsep pada situasi baru dan mempresentasikan hasil kerja kelompok (Silver dalam Wahyuni, 2012).

Proses menganalisis suatu masalah membutuhkan kemampuan memahami keterkaitan antar konsep, sehingga dalam rangka memudahkan siswa dalam belajar diperlukan teknik-teknik pemetaan untuk menguasai konsep-konsep yang hendak dicapai. Menurut Martin (dalam Trianto, 2007: 157), pemetaan konsep merupakan inovasi baru yang penting untuk membantu siswa menghasilkan pembelajaran bermakna dalam kelas. Pemetaan konsep dapat disajikan dalam berbagai tipe. Menurut Nur (dalam Trianto, 2007:161), pemetaan konsep ada empat macam, yaitu pohon jaringan, rantai kejadian, peta konsep siklus, dan peta konsep laba-laba (spider concept map). Spider concept map merupakan salah satu teknik pemetaan yang membantu siswa dalam memahami 
macam-macam konsep yang ditanamkan dari konsep utama menuju anak konsep lainnya yang diajarkan.

\section{METODE}

Penelitian dan pengembangan (Research \& Development) menggunakan modifikasi Borg and Gall (Tim Puslitjaknov, 2008:10-11). Instrumen yang digunakan meliputi angket, observasi, wawancara dan tes. Uji lapangan operasional menggunakan one group pretestpostest design. Data keterampilan proses sains dan kemam-puan menganalisis diuji dengan paired sample $t$ Test dan dihitung menggunakan gain skor ternormalisasi dengan kriteria sebagaimana Tabel 1.

Tabel 1. Kriteria Gain Ternormalisasi

\begin{tabular}{cc}
\hline Nilai $\langle\mathrm{g}\rangle$ & Kriteria \\
\hline$<\mathrm{g}>\geq 0,7$ & Tinggi \\
$0,7><\mathrm{g}>\geq 0,3$ & Sedang \\
$<\mathrm{g}><0,3$ & Rendah \\
\hline
\end{tabular}

Sumber: (Hake, 1998: 1)

\section{HASIL DAN PEMBAHASAN}

Hasil pengembangan modul berbasis problem posing disertai spider concept map terlihat dari beberapa validasi sebagaimana pada Gambar 1.

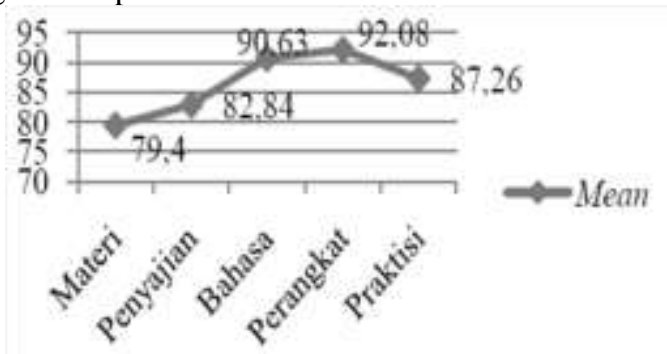

Gambar 1. Grafik Hasil Keseluruhan Validasi Modul

Ciri khas modul pencemaran lingkungan berbasis problem posing disertai spider concept map adalah pada aspek perangkat pembelajarannya dan aspek bahasa yang menunjukkan skor di atas $90,00 \%$ dan paling rendah pada aspek materi sebesar $79,4 \%$.

Aspek keterlaksanaan sintaks pembelajaran berbasis problem posing pada saat proses pembelajaran berlangsung ditunjukkan sebagaimana Gambar 2.

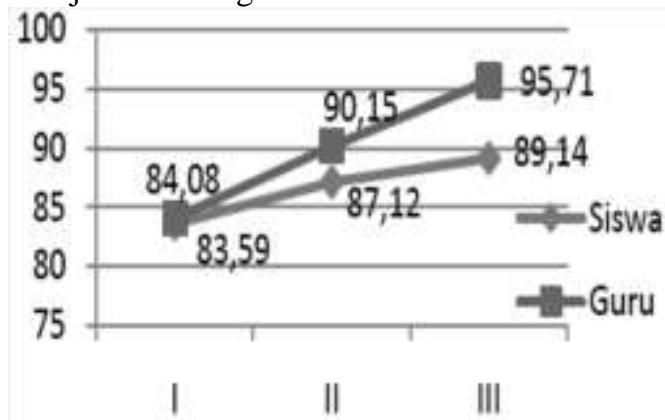

\section{Gambar 2. Grafik Keterlaksanaan Sintaks}

Setelah proses pembelajaran selesai siswa di tes untuk mengetahui hasil belajar di akhir kompetensi dasar. Hasilnya sebagaimana pada gambar di bawah.

\section{Persentase}

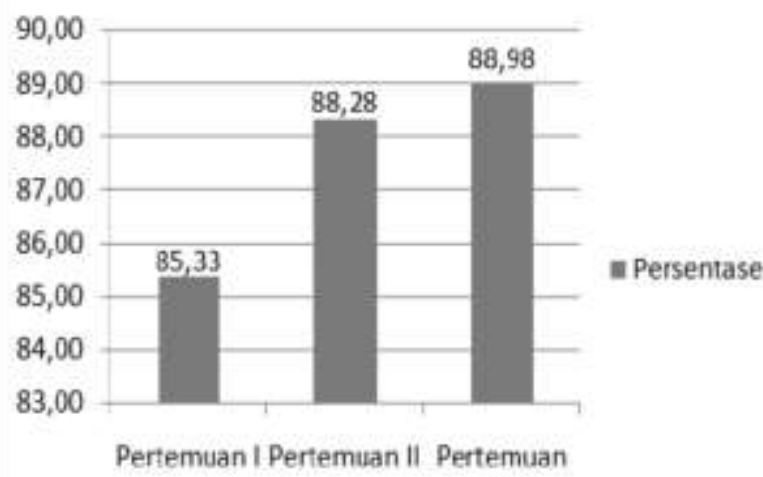

III

Gambar 3. Histogram Hasil Belajar Aspek Sikap

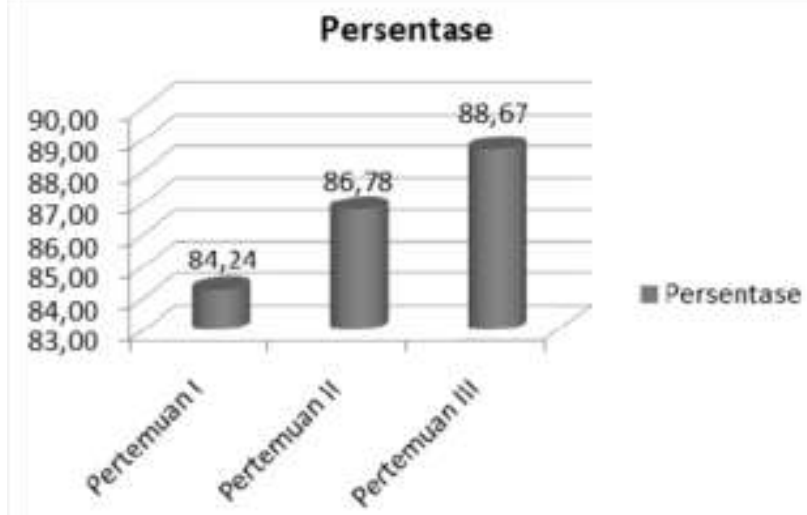

Gambar 4. Histogram Hasil Belajar Aspek Keterampilan

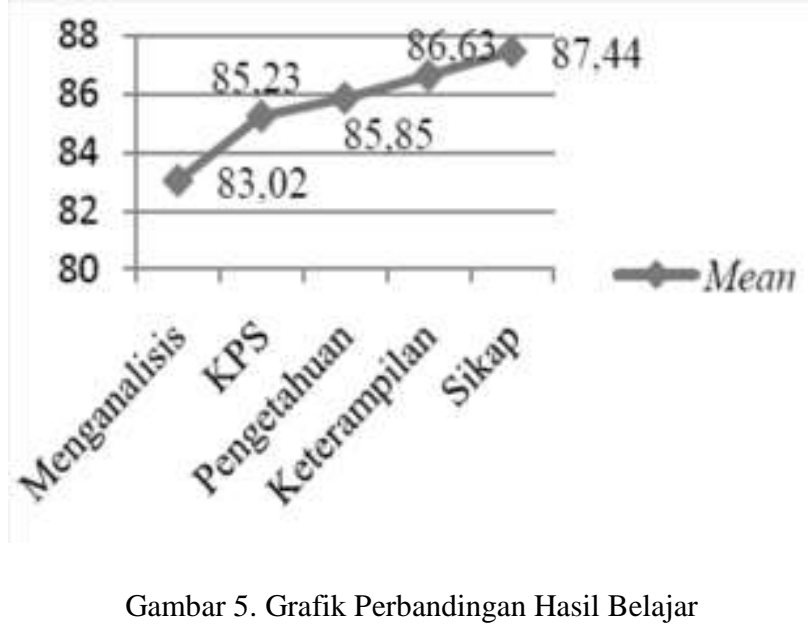

1. Karakteristik Modul

Karakteristik modul 
Pertama, memberi peluang siswa dalam keterampilan proses. Keterampilan proses yang dimaksud dalam modul berbasis problem posing adalah keterampilan proses sains. KPS menurut Dimyati dan Mudjiono (2009), meliputi: mengamati, mengelompokkan/ klasifikasi, menafsirkan, meramalkan, mengajukan pertanyaan, merumusakan hipotesis, merencanakan percobaan, menggunakan alat dan bahan, menerapkan konsep dan mengkomunikasikan. Kedua, kemampuan berpikir siswa. Siswa dituntut untuk melakukan proses berpikir ilmiah melalui berpikir kritis terutama kemampuan menganalisis, yang meliputi: kemampuan menguji ide, mengenali argumen dan mengenali alasan dan pernyataan (Facione, 2001). Proses berpikir tersebut dilalui siswa agar membekali dalam kehidupannya kelak di masyarakat. Ketiga, kemampuan literasi sains yang meliputi empat aspek, yaitu: memahami istilah sains, membaca dalam sains, menulis tentag sains dan berbicara dalam sains (Toharudin, et al., 2011).

\section{Prosedur Pengembangan Modul}

Penelitian dan pengembangan menggunakan modifikasi Borg and Gall (Tim Puslitjaknov, 2008:10-11) terdiri 10 tahapan, meliputi: penelitian pendahu-luan, perencanaan, Pengembangan ben-tuk produk awal, uji coba lapangan tahap awal, revisi produk utama, uji lapangan utama, revisi produk operasional, uji lapangan operasional, revisi produk akhir, diseminasi dan implementasi produk.

\section{Kelayakan Modul Pencemaran Lingkungan Berbasis Problem Posing}

Kelayakan modul ditentukan oleh beberapa validator, praktisi dan pengguna modul dalam hal ini adalah ahli, guru dan siswa. Ciri-ciri modul yang dianggap layak menurut Santyasa (2009), antara lain: 1) Didahului oleh pernyataan sasaran belajar; 2) Pengetahuan disusun sedemikian rupa, sehingga dapat menggiring partisipasi siswa secara aktif; 3) Memuat sistem penilaian berdasarkan penguasaan; 4) Memuat semua unsur bahan pelajaran dan semua tugas pelajaran; 5) Memberi peluang bagi perbedaan antar individu siswa; dan 6) Mengarah pada suatu tujuan belajar tuntas. Kelayakan sebuah modul dapat dilihat dari berbagai aspek. Pertama, berdasarkan aspek penyajian modul. Pada aspek ini didapatkan hasil bahwa modul sudah memenuhi kriteria sebagai modul yang baik untuk digunakan oleh siswa dan guru. Kedua, berdasarkan materi/isi modul. Uraian isi pembelajaran menyangkut masalah strategi pengor-ganisasian isi pembe-lajaran menurut Mehrens \& Lehman (1984), strategi diartikan sebagai strategi yang mengacu ke-pada cara untuk membuat urutan (squencing) dan mensintesis (synthesi-zing) fakta, konsep, prosedur, dan prinsipprinsip yang berkaitan. Ketiga, berdasarkan aspek kebahasaan sebagai gaya komunikasi modul kepada siswa dan guru. Bahasa menjadi bahasa simbolik yang penting sebagai sarana mengko-munikasikan maksud yang hendak dicapai dari modul yang dikembangkan. Modul pencemaran lingkungan berbasis problem posing memi-liki karakteristik kebahasaan yang paling tinggi dibanding lainnya dan hal ini menjadi ciri khusus modul pencemaran lingkungan berbasis problem posing.

\section{Efektivitas Modul}

Efektifitas modul pencemaran lingkungan berbasis problem posing didasarkan pada ada tidaknya kenaikan hasil belajar, keterampilan proses sain dan kemampuan menganalisis.

\section{Hasil Belajar Siswa}

Hasil belajar siswa sebagai salah satu indikator keberhasilan proses pembelajaran meliputi 3 aspek, yaitu: aspek pengetahuan, aspek sikap dan aspek keterampilan. Pertama, berdasarkan hasil analisis aspek pengetahuan dapat disimpulkan bahwa pemberian modul pencemaran lingkungan berbasis problem posing dapat meningkatkan hasil belajar pengetahuan siswa. Wenno (2010: 186), mengemukakan bahwa melakukan pem-belajaran dengan modul membuat siswa lebih mudah memahami konsep/materi sehingga hasil belajar siswa dapat meningkat. Pembelajaran yang baik dan menyenangkan adalah pembelajaran yang memberikan kesempatan kepada siswa tentang ide/gagasan yang dimiliki. Proses pembelajaran tersebut akan mendorong siswa untuk terlibat secara aktif dan membangun pengetahuan, sikap, serta perilaku. Pembelajaran dengan menggunakan modul berbasis problem posing mendorong siswa untuk lebih aktif dalam melakukan eksperimen, membuktikan rumusan masalah, berdiskusi, dan komunikatif dalam menjelaskan hasil eksperimen, sehingga hal tersebut mendorong peningkatan hasil belajar siswa.

Kedua, hasil belajar aspek sikap. Berdasarkan hasil analisis, nilai aspek sikap siswa mengalami peningkatan. Hal tersebut terjadi karena siswa mulai terbiasa dengan modul yang dikembangkan. Siswa juga lebih aktif bekerja sama dengan teman saat praktikum dan diskusi. Depdiknas (2003: 6), mengemukakan bahwa diskusi merupakan salah satu kondisi belajar yang sesuia dengan filosofi konstruktivisme karena dalam diskusi siswa dapat mengungkapkan gagasan, melakukan penelitian secara sederhana, demonstrasi, juga kegiatan lain yang memberikan ruang kepada siswa untuk dapat mempertanyakan, memodifikasi, atau mempertajam gagasannya. Selain diskusi siswa juga sebaiknya diberikan kesempatan berinteraksi dengan anggota kelompoknya. Gulo (2004: 130), mengemukakan di dalam kelompok, sesorang berbicara, yang lain mendengar, ada juga yang bertanya, dan ada yang menjawab. Diskusi kelompok berjalan dengan lancer jika ditunjang dengan sumber informasi seperti buku, atau narasumber. Johnson (2009: 166), ber-pendapat bahwa setiap pengetahuan yang dimiliki seseorang dalam kelompok akan men-jadi output bagi anggota kelompok lain, dan output ini akan menjadi input bagi yang lain. Jika setiap individu yang berbeda mam-bangun hubungan dengan cara tersebut, maka akan terbentuk suatu sistem yang baik di dalam kelompok.

Ketiga, hasil belajar aspek keterampilan. Hasil belajar aspek keterampilan juga mengalami kenaikan pada tiap pertemuan karena siswa telah terbiasa dengan metode praktikum, maka keterampilan siswa dalam penggunaan alat juga semakin baik. Depdiknas (2003: 7), mengemukakan bahwa pelajaran sains memfokuskan kegiatan pada penemuan dan pengolahan informasi melalui kegiatan mengamati, mengukur, mengajukan pertanyaan, mengklasifikasi, memecahkan masalah, dan 
sebagainya. Hal senada juga dikemukakan oleh Rahayu, et al. (2013: 133), menyatakan bahwa nilai rata-rata aspek keterampilan mengalami peningkatan karena siswa terlibat aktif dan lebih terarah saat praktikum.

\section{Keterampilan Proses Sains}

Hasil belajar untuk keterampilan proses sains menunjukkan peningkatan dibandingkan dengan sebelum pembelajaran dilakukan. Modul pencemaran lingkungan yang dikemas dengan teknik praktikum membuat siswa menjadi lebih termotivasi dan mengasah keterampilan proses sains. Menurut Deden (2013), menyatakan bahwa melalui kegiatan praktikum keterampilan proses sains siswa dapat ditingkatkan. Keterampilan proses sains terdiri atas beberapa bagian menurut Ango (2002), terdiri dari sebelas keterampilan yaitu, observing (observasi), classifying (klasifikasi), iffering (menafsirkan), predicting (prediksi), commumicating (komunikasi), interpreting data (interpretasi data), making operational definitions (menerapkan konsep), posingquestions (mengajukan pertanyaan), hyphothesing (hipotesis), experimenting (bereksperimen) and formulating (membuat eksperimen).

Keterampilan proses sains merupakan kemampuan prosedural yang diperlukan untuk melalukan kegiatan seperti praktikum atau pengetahuan tentang cara" melakukan sesuatu. Pengetahuan ini mencakup pengetahuan tentang keterampilan, algoritma, teknik, dan metode (Dochy, 1995). Pengetahuan prose-dural ini terbagi menjadi tiga subjenis yaitu: 1) Pengetahuan tentang keterampilan dalam bidang tertentu dan algoritma; 2) Pengetahuan tentang teknik dan metode dalam bidang tertentu; dan 3) Pengetahuan tentang kriteria untuk menentukan kapan harus menggunakan prosedur yang tepat.

\section{Kemampuan Menganalisis}

Kemampuan menganalisis meru-pakan kemampuan siswa untuk mengu-raikan atau memisahkan suatu hal ke dalam bagian-bagiannya dan dapat mencari keterkaitan antara bagian-bagian tersebut. Tuntutan dalam kemampuan analisis adalah memisahkan materi (informasi) ke dalam bagian-bagiannya yang perlu, mencari hubungan antarabagian-bagiannya, mampu melihat (mengenal) komponen-komponennya, bagaimana komponen itu berhubungan dan terorganisasikan, mem-bedakan fakta dari hayalan. Kemampuan analisis didalamnya juga termasuk kemam-puan menyelesaikan soal-soal yang tidak rutin, menemukan hubungan, membuktikan dan mengomentari bukti, dan merumuskan serta menunjukkan benarnya suatu generali-sasi, tetapi baru dalam tahap analisis belum dapat menyusun. Pendapat lain menurut Suherman dan Sukjaya (1990: 49), menyatakan bahwa kemampuan analisis adalah kemampuan untuk merinci atau menguraikan suatu masalah (soal) menjadi bagianbagian yang lebih kecil (kom-ponen) serta mampu untuk memahami hubungan diantara bagian-bagian tersebut. Hal ini juga diperkuat oleh Bloom yang me-nyatakan bahwa kemampuan berpikir analitis menekankan pada pemecahan materi ke dalam bagian-bagian yang lebih khusus atau kecil dan mendeteksi hubungan-hubungan dan bagian-bagian tersebut dan bagian-bagian itu diorganisir. Menurut Xia et al. (2008: 154), pembelajaran yang melibatkan aktivitas problem posing dapat menimbulkan ketertari-kan siswa terhadap pelajaran, mening-katkan kemampuan mereka dalam mengajukan masalah dan meningkatkan kemampuan belajar dengan baik. Hasil ini juga sesuai dengan apa yang dinyatakan oleh Cai (2003), menyatakan bahwa problem posing dapat meningkatkan penalaran dan refleksi untuk pemahaman yang lebih dalam. Sintak problem posing membiasakan siswa untuk melatih kemampuan siswa dalam menganalisis berbagai permasalahan hingga menemukan solusi dari permasalahan tersebut. Menurut Cankoy et al., (2010:12), dengan diberikan pembelajaran problem posing lebih baik dari pada siswa yang tidak diberikan pembelajaran dengan problem posing dalam menyelesaikan tes pemahaman masalah. Hal senada juga disampaikan Lee (2010:12), bahwa kemampuan siswa dalam memecahkan masalah meningkat sete-lah diberikan pembelajaran problem posing.

Hubungan diantara pengajuan masalah dengan kemampuan menganali-sis terletak pada menguji ide dalam pengajuan masalah mengacu kepada kemampuan siswa membuat masalah sekaligus penyelesainya dengan beragam dan benar, mengenali argumen dalam pengajuan masalah mengacu pada kemam-puan siswa memiliki cara penyelesaian berbeda-beda terhadap masalah yang diajukannya namun masalah yang diajukan masih memiliki keterkaitan dan mengenali alasan atau pernyataan dalam pengajuan masalah mengacu pada kemampuan siswa dalam me-ngajukan masalah yang berbeda dari masalah yang diajukan sebelumnya dan siswa tahu mengapa mengajukan masalah tersebut.

\section{Keterkaitan Problem posing Disertai Spider Concept Map Terhadap Hasil Belajar}

Hal terpenting dari sintaks problem posing yang dapat memberda-yakan kemampuannya adalah kemam-puan mengajukan masalah, keterkaitan pembuatan soal dan pemecahan masalah diungkapkan. English (1997), menyata-kan bahwa membuat soal/ masalah berarti tahap awal dalam meme-cahkan masalah, yaitu memahami soal telah terlewati, sehingga untuk menyelesaikan soal dengan tahap berikutnya akan terbuka. Semen-tara itu Silver dan Cai (1996), menyatakan bahwa kemampuan pembuatan soal ber-korelasi positif dengan kemampuan pemecahan masalah. Hal tersebut juga sesuai dengan pendapat bahwa Ahmad dan Zanzali (2006: 7), bahwa siswa seharusnya di dalam proses belajar mengajar digunakan pendekatan alternatif yang membuat siswa berkesem-patan untuk mengajukan masalah. Dalam mengajukan masalah, kemampuan siswa dalam mengexplore pengetahuannya tidak terbatas, sehingga terkadang hal ini di luar dari pemahaman guru. Melalui aktivitas ini dimungkinkan pengetahuan siswa melampaui apa yang kita harapkan karena peserta diberikan keleluasaan untuk mengeluarkan berbagai idenya. Problem posing pada intinya adalah meminta siswa untuk mengajukan soal atau masalah yang diajukan dapat berdasar pada topik luas, soal yang sudah dikerjakan atau informasi tertentu yang diberikan oleh guru (Ketut, 2004).

Dalam pengajuan masalah atau soal oleh siswa hendaknya didasarkan pada situasi yang diberikan oleh 
guru. Situasi dalam hal ini bisa berupa infor-masi (pernyataan), per-tanyaan dan seba-gainya. Pengajuan soal juga merupakan kegiatan yang mengarah pada pembentukan sikap kritis dan kreatif, karena dalam pengajuan soal siswa diminta membuat pertanyaan dari informasi yang diberikan guru (Dinawati, 2001).

Berdasarkan uraian di atas, dapat disimpulkan bahwa kekuatan model problem posing terletak pada kemampuan siswa dalam membuat/ mengajukan masalah. Adapun kelemahan utama menurut silver dalam Ika (2011), terletak juga terletak pada penguasaan bahasa dimana siswa mengalami kesulitan dalam membuat kalimat tanya. Kelemahan ini apabila dapat dilampaui siswa, maka akan mampu melewati tahapan-tahapan berikutnya, karena dengan membuat soal/masalah berarti tahap awal dalam meme-cahkan masalah, yaitu memahami masalah telah terlewati, sehingga untuk menyelesaikan soal dengan tahap berikutnya akan lebih terbuka. Sehingga diharapkan pada proses pembelajan siswa akan mampu menemukan solusi dari permasalahan. Siswa yang telah menemukan solusi akan mampu menerapkan pengetahuannya pada situasi baru dengan catatan memiliki kemiripan permasalahan, dengan demikian tentu akan berkorelasi positif dengan hasil be-lajarnya.

Siswa yang telah menggunakan pemetaan menemukan bahwa peta konsep memberi mereka basis logis untuk memutuskan ide utama apa yang akan dimasukkan atau dihapus dan rencana-rencana dan penga-jaran sains mereka. Konsep utama akan mem-bantu dalam merumuskan konsep-konsep lainnya dengan baik. Jenis pemetaan yang memungkinkan diterapkan antara lain teknik spider concept map.

Spider concept map lebih mem-bantu untuk memperbesar struktur pengetahuan. Dari hasil penelitian, menunjukkan siswa merasa lebih baik pada spider concept map. Proses berpikir siswa dengan menggunakan spider concept map menggunakan pola tidak hierarkis, membawa kemudahan dan keluasan dalam menemukan konsepkonsep tidak terbatas. Konsep yang didapatkan berasal dari proses berpikir siswa dalam mene-mukan pengetahuan mereka (pembelajaran bermakna) dengan pola pikir yang umum dan luas memung-kinkan siswa untuk membuat konsep yang utama hingga konsep-konsep lainnya yang saling berhubungan satu sama lainnya. Selain konsep, siswa juga dapat merumuskan contohcontoh dalam cabang konsep yang merupakan penja-baran dari kekhususan konsep, sehingga mudah dipamahi. Pemetaan menurut Goodman (1984), Mason (1992) dan Minstrell (1989), bahwa pemetaan konsep membantu dalam ilmu pembe-lajaran dan secara langsung menempatkan dampak pada prestasi.

\section{KESIMPULAN}

Karakteristik modul berbasis problem posing, diantaranya: memberi peluang kepada siswa untuk mengemban-gkan keterampilan proses sains, kemampuan berpikir dan kemampuan literasi sains.
Penelitian dan pengembangan menggunakan modifikasi Borg dan Gall (Tim Puslitjaknov, 2008:10-11) terdiri 10 tahapan, meliputi: penelitian pendahu-luan, perencanaan, mengembangkan bentuk produk awal, uji coba lapangan tahap awal, revisi produk utama, uji lapangan utama, revisi produk operasional, uji lapangan operasional, revisi produk akhir, diseminasi dan implementasi produk.

Kelayakan modul Pencemaran Lingkungan berbasis problem posing disertai spider concept map ditunjukkan melalui hasil validasi aspek penyajian, aspek kebahasaan, aspek materi dan perangkat pembelajaran yang mendapatkan skor rata-rata 3,51 dengan berkategori "sangat baik".

Modul Pencemaran Lingkungan berbasis problem posing disertai spider concept map efektif memberdayakan KPS dengan $\mathrm{N}$-gain score sebesar 0,60 dengan kategori "sedang" dan kemam-puan menganalisis dengan $N$-gain score sebesar 0,57 dengan kategori "sedang".

Saran yang dapat diberikan dari penelitian ini adalah modul pencemaran lingkungan berbasis problem posing ini dapat diterapkan pada meteri pencemaran dan dijadikan salah satu contoh pengembangan bahan ajar oleh guru. Kelemahan modul berbasis problem posing terletak pada sintaks pengajuan masalah, karena siswa kesulitan dalam bahasa ketika akan membuat kalimat tanya, modul pencemaran lingkungan berbasis problem posing mungkin dapat dikembangkan untuk materi lain yang sesuai.

\section{DAFTAR PUSTAKA}

Adi, M. 2009. Upaya Peningkatan Aktivitas Belajar dan Kemampuan Kognitif C1-C3 Melalui Pendekatan Problem Posing Pada Pembelajaran Biologi Materi Klasifikasi Makhluk Hidup untuk Siswa Kelas VII b MTSN Bantul TA 2008/2009. Yogyakarta: UIN Sunan Kalijaga

Ahmad, S. dan Zanzali, N. 2006. Problem Posing Abilities in Mathematics of Malaysian Primary year 5 Children: An Exploratory Study. Jurnal Pendidikan Universitas teknologi Malaysia, 1-9

Balitbang Kementerian Pendidikan dan Kebudayaan. 2013. Hasil Ujian Nasional SMA/SMK se-Indonesia. Jakarta: Kemendikbud

Cai, J. 2003. Singaporean Students' Mathematical Thinking in Problem Solving and Problem Posing: an Exploratory Study. International Journal of Mathematics Education in Science and Technology, 34 (5): 719 - 737

Cankoy, O. and Darbaz, S. 2010. Effect or Problem posing Instruction on undertsanding Problem. H. U. Journal of Education. 38: 11-24

Deden. 2013. Peningkatan Keterampilan Proses Sains Menggunakan Metode Eksperimen Dalam Pembelajaran IPA Kelas VI Sdn 47 Rambin Sanggau. Pontianak: Universitas Tanjungpura

Departemen Pendidikan Nasional. 2003. Sains. Jakarta: Pengembangan Sistem dan Pengendalian program 
Dimyati dan Mudjiono. 2009. Belajar dan Pembelajaran. Jakarta: Rineka Cipta

Dinawati, T. 2001. Pengajuan Soal (Problem posing) sebagai Upaya Meningkatkan Pemahaman Siswa dalam Belajar Matematika di Sekolah. Jurnal Teknobel, Maret 2001, Vol. 2(1): 64-65

Dochy, F., dan Alexander, P. 1995. Mapping Prior Knowledge: A Framework of Discution among Researcher. European Journal of Psychology in Education, 10: 224 - 242

English, L. D. 1997. Promoting a Problem Posing Classroom. Teaching Children Mathematics Journal. November 1997: $172-179$

Facione, P.F. 2001. California CT skill test. Millbrae, CA: California Academic Press

Goodman, J. 1984. Relation and teacher education: A case study and theoretical analysis. Interchange, 15(3): 9-26

Gulo, W. 2004. Metodologi Penelitian. Jakarta: Grasindo

Kementerian Pendidikan dan Kebudayaan. 2013. 8 Standar Nasional Pendidikan. Jakarta: Kemendikbud

Kementerian Pendidikan dan Kebudayaan. 2014. Dokumen Kurikulum 2013. Jakarta: Kemenndikbud

Ketut, S. 2004. Pembelajaran dengan Pendekatan Problem Solving dan Problem Posing Untuk Meningkatkan Aktivitas Siswa. Jurnal Kependidikan, Mei 2004, Vol. (1): 52

Lee, S. 2010. The Effect of Alternative Solutions on Problem posing. Taipei Municipal University of Education Vol. 1(1): $1-17$

Mason, C.L. 1992. Concept mapping: A tool to develop reflective science instruction. Science education, 76(1): 5163

Mehrens, W. A. and Lehmann, I. J. 1984. Measurement and evaluation in education. Newyork, ELC

Minstrell, J.A. 1989. Teaching science for understanding. In L.B. resnick \& L.E klopfer (Eds) towards the thinking curriculum: cognitive research 1989. ASCD Year book

PISA. 2013. Results in Focus: Programme for International Student Assessment Volume VI, Students and Money: Financial Literacy Skills for the 21st Century (forthcoming, 2014), examines students experience with and knowledge about money. psychology, Third edition. New York: Holt, Rinehart and Winston

Puslitjaknov. 2008. Penelitian dan Pengembangan. Jakarta: Raja Grafindo Persada

Putranto, P.E. 2010. Penerapan Model Pembelajaran Kooperatif Tipe Circ Berbantuan Modul Untuk Meningkatkan Keaktivan Dan Hasil Belajar Siswa Kelas VIIIA MTs N 1 Gemolong Tahun Ajaran 2009/2010. (Jurnal Skripsi Tidak Dipublikasikan: Surakarta: FKIP UNS)

Rahayu, S., Widodo, A.T, dan Sudarmin. 2013. Pengembangan Perangkat Pembelajaran Model Berbantuan Media "I Am A Scientist". (Jurnal Tesis Tidak Dipublikasikan: Prodi Pendidikan IPA, Program Pascasarjana, Universitas Negeri Semarang)
Santyasa. 2009. Metode Penelitian Pengembangan dan Teori Pengembangan Modul. Bali: Undiksha

Silver, E. and Cai, J. 1996. An Analysis of Aritmatic Problem Posing by MiddlenSchool Students. Journal for Research in Mathematis Education, Vol.2(5). November 1996: 521 539

Suciati. 2011. Membangun Karakter Peserta Didik Melalui Pembelajaran Biologi Berbasis Keterampilan Proses. Prosiding. Seminar Nasional VII Pendidikan Biologi FKIP UNS

Suherman, E. dan Sukjaya, Y. 1990. Petunjuk Praktis untuk Melaksanakan Evaluasi Pendidikan Matematika. Bandung: Wijayakusumah 157

Toharudin, U., Hendrawati, S., Rustaman, A. 2011. Membangun Literasi Sains Peserta Didik. Bandung: Humaniora

Trianto. 2007. Model-model Pembelajaran Inovatif Berorientasi Konstruktivistik. Jakarta: Prestasi Pustaka

Wenno, I. H. 2008. Strategi Belajar Mengajar Sains Berbasis Kontekstual. Yogyakarta: Inti Media

Xia, X., Lü, C., Wang, B. 2008. Research on Mathematics Instruction Experi-ment Based Problem Posing. Journal of Mathematics Education, Vol. 1(1):153-16 